\title{
15 Archives, truth and the democratic transition process in Brazil $^{1}$
}

\author{
Aluf Alba Vilar Elias
}

\section{The military regime: Brazil and Latin America}

The military dictatorship in Brazil was not an isolated case in Latin America. Other Southern Cone countries were subjected to similar abusive and violating regimes, which were borne out of the disputes emerging from a new global political and economic order at the time. In all of them, the Armed Forces played a lead role in constitutional breaches and the practice of violent and arbitrary acts: Paraguay (1954), Brazil (1964), Argentina (1966 and 1976), Uruguay (1973) and Chile (1973). The working class was controlled by enforcement in the unions, with arrests, assassinations of their leaderships and other direct actions. Political parties were dissolved and parliaments, in almost all cases, were closed or subjected to strict limitations, in addition to the disappearances, torture, murders and kidnappings of members of civil society. In the 1970s, there was integration between the five countries in coordinated acts of political repression against anti-regime citizens, which included the exchange of military intelligence for arrests, torture, surveillance, kidnapping and murders, etc.

When the military governments came to an end, a series of court cases was begun to assign responsibility and punishment to the perpetrators, principally the authorities in command at the time. Although Brazil officially recognised its responsibility through the Commission on Deaths and Disappearances in 1995, it took the unusual position of not carrying out a similar assessment of the serious violations of human rights that had taken place. It should be noted that the Southern Cone countries revised their amnesty laws, except Brazil, and established truth commissions. The social and international unrest caused by the lack of revision to the Amnesty Law in Brazil, of 1973 reveals the incompleteness of the redemocratisation process.

Not punishing perpetrators implies a suspension of the right to forgiveness and the truth, an imposed amnesia, weakening the work following the recommendations from the national truth commissions, increasing the risk of lost memory and forgetting. It concerns making use of the right to the truth as a resource for memory and justice. As Paul Ricoeur (2010) taught, to make a memory is to fight against forgetting, and forgiveness is what 
restores the power to act. The self-amnesty that took place in Brazil made it impossible to distinguish between Justice, with a capital letter to signify the institutional sense, and justice.

\section{Transitional justice}

Paul Van Zyl (2009) defines transitional justice "as an effort made towards sustainable peace after a period of conflict, mass violence or systematic violation of human rights". Its objective, according to the author, consists in "prosecuting the perpetrators, revealing the truth about past crimes, providing reparation to victims, reforming the institutions that perpetrated abuse and promoting reconciliation". He highlights how the scope of transitional justice has widened and developed in the last decade, in two relevant ways: the first relates to the conceptual elements of transitional justice that became legal obligations; the second corresponds to strengthening democracy.

The greater application of international law that has taken place in the last 20 years, due to the efforts of bodies such as the European Court of Human Rights, the Inter-American Court of Human Rights and the UN Human Rights Committee, has stimulated the establishment of clear standards with regard to State obligations in confronting human rights violations, as well as the prohibition of amnesties in these cases, given the imprescriptible nature of their crimes.

The first question that arises when discussing transitional justice in Brazil, whether as a policy with concrete actions or as a valid concept within a proposed universalism, is that of its very existence: is justice possible in the middle of the democratic transition process?

Quinhala (2013) questions the application of the concept of Transitional Justice in Brazil and in other Latin American countries. According to the author, the term, originating in the political sciences and international law, concerns the political and juridical measures undertaken during the period in which an authoritarian regime is substituted by a democratic regime. When introduced into an unstable environment, justice can never be fully delivered, because the political conditions are unable to implement it. The measures must balance different interests: those of the victims who demand justice, of the authoritarian governments and the new political leaderships concerned with ensuring democratic stability. Seeking to fulfil different tasks, the measures end up being considered unfair by all, as they are undertaken in the context of social tension. However, neglecting them can cause serious consequences such as the impunity of violence and damage to fundamental rights.

The succession of authoritarian, repressive and violent regimes suffered by Latin America caused deep social harm that remains underdressed. According to Genro (2010), the discourse had been fixed to portray the period as peaceful with economic advances, providing the basis for the current order and democracy. As a result of this, for the author, the governing 
bodies sought to establish a pact of silence, to avoid reviving the past in fear of bringing unhealed wounds to the surface. This kind of political use of memory in fact constitutes non-memory, as re-establishing it cannot be done without a conflict of values.

Amongst the approaches adopted in the Latin American context, memory politics are highlighted as an instrument used to redefine historical memory in order to further develop a democracy tarnished by abuses, excesses and violations. This is not only through memorials or public spaces designed for this purpose, but also through the use of archives as parts of this process, be it in their symbolic form (vestiges and monuments of the past), as a legal instrument (opening the archives relating to violations and their use as documentary evidence) or as extracts of discourse and forms of truth that communicate and fix narratives and ideologies that conflict with and/or nullify each other in a constant battle for memory.

Equally, it should be noted that a correct model of transitional justice does not exist, only one that is best suited to the specific social demands of those who were subjected to the abuses and had their rights violated.

\section{The National Truth Commission and the use of archives}

The concept of truth does not fit within the methods of adequacy, verification or falsifiability. Its scope is outlined, as Foucault stressed (2008), in discussions concerning its general politics, which are the discourses that it accepts and makes function as true. The specific effects of power will determine the set of rules by which we distinguish truth from falsehood. These effects are traversed by a need for truth which is connected to economic and political forces, being a constant object of social conflict and ideological struggles.

Within this argument, there is space to think about the procedures and techniques valued in obtaining the truth, which are undoubtedly influenced by scientific discourse and institutions. The model employed by the NTC certainly embraced this path, in which playing truth against falsehood would be capable of indicating what, by choice, is true. The weight of the State is felt in this intersection. Its institutions were put in place to discover and recognise the facts and their potential contradictions, by means of their apparatus, represented, among others, by Justice, and by the archives and their sources.

Ethical responsibility in reading historical narrative that, for Benjamin (2010), is not a continuous process, but rather a diversion with multiple branches, is defined by giving space to the history of the excluded, the defeated and the victims. It allows them to redefine their places in time, by permitting their voices and rewriting the uncertain past fairly, thereby combating the forgetting which is authorised by impunity. For this, archives are called to speak, and their words do not always correspond to their place of origin, as historical time, disputes or choices can offer them a new reading 
or a new argument. This has perhaps been one of the major challenges for the NTC: how to recover words from a place and time that no longer exist? We cannot forget the sensitivity of the facts in question and the complexity that is therefore involved: we are dealing with traumas, with searches for missing, dead and barbarously tortured loved ones, with recognition, retractions, accountability, etc. How does one collate memories from traumatic periods without injuring the dignity of individuals? How can one promote a fair narrative?

Every national working experience of truth commissions around the world has its own particular way of trying to find a path to justice to reconcile a traumatic past with a peaceful present, be it via the legal framework or through hearings that expose the versions silenced by violent repression. The way in which social groups chose that which satisfied their demands or the power relations involved in the process ranged from requests for forgiveness and recognition to criminal accountability. In the Brazilian case, the NTC was presented within a programme of government public policies focused on guaranteeing human rights, by establishing politics of memory with the objective of discovering, clarifying and recognising past abuses, giving a voice to the victims, without any punitive, persecution or judicial element.

The delay in implementing the NTC, which happened 27 years after the military regime, scant transparency and the lack of public dialogue about its implementation model, investigative methodology, workings and objectives, was a target for criticism from the social groups that had been fighting for decades for a revision to the Amnesty Law, for the establishment of responsibilities and for the truth of the whereabouts of the disappeared. This negotiated transition with no punitive element made it unviable to establish legal cases capable of judging and convicting the individuals who carried out persecutions and political crimes, causing more frustration.

Despite this, the NTC promoted extremely relevant political movements, discussions and déente for the country in terms of organised civil society. Many issues were revisited and debated, such as unrestricted access to the archives from the military regime period and the right to the truth and memory. Its implementation also provided an opportunity to locate the archives surrounding the military activities of the time, as it was equipped with powers to requisition documents, question people and carry out investigations.

Created by Law 12.528 , in 2011, sanctioned by the then President Dilma Rousseff, the NTC's objective was to: "Examine and clarify the serious violations of human rights committed ... in order to realise the right to memory and historical truth and encourage national reconciliation”, aiming, according to a message sent from the President of the Republic, Luiz Inácio Lula da Silva, to National Congress when the project was delivered (Brazil, NTC 2014, v.1), "to respond to a historical demand from Brazilian society to ensure the retrieval of memory and strengthening of democratic values". 


\section{Aluf Alba Vilar Elias}

With regard to its structure and internal workings, the NTC was organised in a collegiate model composed of seven council members nominated by the President of the Republic, at its inauguration on 16 May 2012.

The initial phase of its activity, between May and November 2012, consisted of administrative organisational activities, in planning the research work, contacting the relatives of victims and in defining the issues to be investigated. In July, the members formed three topical subcommittees: I subcommittee for research, generation and organization of information; II - subcommittee for "relations with civil society and institutions; III subcommittee for external communication. In December of the same year, development of the research work began, coordinated by the members of the Collegiate body with the support of advisers, consultants and researchers. Thirteen topical working groups were also established (BRAZIL, NTC 2014, v.1, p. 50-51).

From November 2013, the core expert body was formed to clarify the circumstances of the deaths and disappearances, as well as locations and methods of torture among other things. To this end, they carried out interviews, exhumations and searches, collated statements and produced documents which made up various reports. Public hearings were also encouraged, with the intention of listening to the victims, witnesses and agents of the repression. These hearings took place in more than 14 States, with the support of civil society and the state and municipal truth commissions, making a total of 80 events in which 565 testimonies were collected (BRAZIL, NTC 2014, v.1, p. 53-54).

Between February and August 2014, public hearings and sessions were organised to present the preliminary research reports. Eight presentations were arranged with live online streaming and press monitoring.

In total, from its inauguration on 16 May 2012 until 31 October 2014, the NTC gathered 1,116 testimonies, with 483 from public hearings and 633 in private (BRAZIL, NTC 2014, v.1, p. 55). The methodology used in the investigative and research procedures involved in the NTC's work appears unclear in its Final Report, which was met with criticism from the civil bodies engaged in monitoring it.

An analysis of the Final Report found no sections that deal exclusively with describing the methodology used in the investigations promoted by the NTC. Using the search term "methodology", sections were found within the topics "Assessments and inquirie" and "Gathering testimonies and statements from agents of the repression", in which the report highlights the use of official documents and oral testimonies to "reconstruct the facts" and the use of "material elements", but there is no more in-depth technical description or mention of the motive and scientific arguments that led to these methodological choices.

Another aspect found in the report was the importance given to the partnership created with the National Archives, specifically the logistical support offered by the institution, extensive access to its documents, IT 
infrastructure support for digitalisation, the availability and access to millions of documents, the access to and use of its database which holds information on other archival institutions in Brazil, facilitating data connections and online research and the gathering of the fonds created and accumulated by the NTC in the course of its activities for the institution.

\section{Archives and truth}

Although it is evident that the role of the National Archives in the functioning and completion of the NTC's work has been recognised, it is important to understand in what way the archival documents were used in this process and their role in affirming a truth. For this purpose, we refer to the interview carried out by Santana and Stampa (2014) with the NTC's ex-coordinator, Rosa Maria Cardoso, who stated that the use of archival documents had been greatly important for the research as well as to understand what happened in the past, but not as the exclusive source of truth or the facts.

Archival documents were key, together with oral testimonies, to the NTC's activities, but Rosa M. Cardoso lamented the difficulties caused by the lack of personnel specialised in handling documents who could adequately extract the information they were looking for. There was an urgent need to demonstrate facts, but supporting evidence to confirm them was lacking, creating gaps in the narratives that were difficult to fill.

By combining this perspective with the criticisms made about an unclear investigative methodology on the part of the NTC, it becomes clear that the demands of the restricted political interests in its creation and operation meant a fundamental part of the planning was passed over: an epistemological reflection on the uses and social functions of the archives and their documents.

No direct connection was found with the notion of truth guided by the uses of archives. On the contrary, it is noted that the use of oral testimonies had a greater role in the reconstruction of narratives, perhaps because of a methodological gap as previously discussed. Archival documents appear to be an auxiliary resource used in conjunction with oral testimonies. This is how their function was determined by the NTC's practices, by evoking the power/authority of the document, in the construction of socio-historical and political processes for institutionalising forms of truth, as a power which was activated discursively by the orality of the testimonies.

A contradiction was found, however, between the discursive uses of the archive versus the ideology of the document "to reconstruct the fact": although the NTC had reproduced, in some ways, the ideology of documentfact or archive-truth, its real investigative practices prioritised the use of oral testimonies, placing archival documents in an indicative position rather than fact, valuing the networks of meaning that circumvented those sources, whose discourses were compromised by belonging to the context of the military regime. 
Agamben, in the work entitled What Is Left of Auschwitz (2008), says that what remains is that which cannot be archived, the word. The testimony is pushed into the background by the language between that which can be said and that which is in fact said. As such, for him, the survivors' testimony of an extreme situation is the only possible account of an unprecedented and unimaginable barbarism. Only those survivors can establish their own terms, the truth of what they saw and lived, as the tragic experience they went through, singularly, made them unique witnesses to the unimaginable.

As such, the oral accounts of those who survived traumatic and unprecedented acts of violence become part of the archive which was not written, but formed by the word that is now on record, taking the material form of a document archivable by the NTC, protected by an institutional bias, e.g. National Archives, generating social effects (Frohmann, 2012): establishing the document-effect (Freitas, 2009) in processes of legitimisation, authority and truth regimes.

\section{Final considerations}

To contest the past is to be free to construct future, as well as present, possibilities; it is to work to diminish the normalisation of evil, of crime, of the heinous. The role of the archives in this objective is characterised by various nuances. On one hand, archival documents may act as possible vehicles of hidden or criminal truths, but, on the other hand, they may also contribute the right to exercise forgiveness, to truth and to memory by offering resources for society to free itself from traumatic memories, redefining historical narratives through certain discourses which were silenced in unfair disputes.

The constitution of archives is directly related to the agencies of truth, even as an instrument or apparatus of the state. Derrida (1995), furthermore, stresses that archiving produces as much as it registers an event, and as such it is our political experience of the so-called news media.

The search for truth promoted by the NTC's activities broke in some way with the notion of an intrinsic archival truth, even if discursively it was being driven by means of other elements such as justice or the right to the truth. The forms of truth are, in this way, more a resource for the construction of archives than the archives are for the construction of a truth, considering truth as a path on which the obscure points, the payments and the silencings are important.

\section{Note}

1 Aspects of this article are part of the research developed for the author's doctoral thesis which was supervised by Professors Georgete Medleg Rodrigues (University of Brasilia) and Lídia Silva de Freitas (Fluminense Federal University). 


\section{Bibliography}

Agamben, Giorgio. 2008, O que resta de Auschwitz: arquivo e o testemunho (Homo Sacer III). São Paulo: Boitempo Editorial, p. 175.

Benjamin, Walter. 2010, "Sobre o conceito da Historia," in: O anjo da história. Lisbon: Assírio \& Alvim.

Brazil. National Truth Commission. 2014, Report/National Truth Commission: Electronic Source. Brasilia: NTC.

Derrida, Jacques. 1995, Mal d'Archive: une impression freudienne. Éditions Galilée. English translation first published, “Archive Fever: A Freudian Impression," Diacritics, vol. 25 , no. 2.

Elias, Aluf Alba V. 2017, Arquivo, verdade e o proceso de transição democrática no Brasil: o legado da Comissão Nacional da Verdade para a ampliaçãoo da discusão epistemológica arquivística. (Doctoral Thesis), Brasilia.

Foucault, Michel. 2008, Microfísica do poder. São Paulo: Graal.

Freitas, Lídia S. 2009, Documento e poder: uma arqueologia da escrita. Post-Doctoral Research Report. Post-Graduate Social Anthropology Program. National Museum, UFRJ.

Frohmann, Bernd. 2017, Documentasõ rediviva: prolegómenos a uma (outra) Filosofia da Informasão. Available at www.seer.unirio.br/index.php/morpheus/ article/view/4828, accessed August 2017.

Genro, Tarso. 2010, Dereito, Constitução e transição democrática no Brasil. Brasilia: Francis.

Quinhala, Renan Honorio. 2013, Justiçc de transição: contornos de conceito. Sao Paulo: Outras expressõe, Dobra Editorial, p. 252.

Ricoeur, Paul. 2007, A memória e história, o esquecimento. Campinas, SP: Unicamp.

Santana, M. A., and Stampa, Inez. 2014, "Interview with Rosa Cardoso, Member of the National Truth Commission," Acervo, vol. 27, no. 1, pp. 11-16, January, June, Rio de Janeiro.

Van Zyl, Paul. 2019, "Promovendo a Justiça Transicional em Sociedades Pós-Conflito," Revista de Anistia Política e Justiça de Transição, vol. 1, January, June. Brasilia Ministry of Justice. 